\title{
30 AN EPISTEMOLOGY OF ORGANIZATIONAL EMERGENCE: The Tripartite Domains of Organizational Discourse and the Servitization of IBM
}

\author{
Michelle Carter \\ Department of Management \\ Clemson University \\ Clemson, SC U.S.A. \\ Hirotoshi Takeda \\ Computer Information Systems \\ Georgia State University \\ Atlanta, GA U.S.A. \\ Centre de Recherche en Management et Organisation \\ University of Paris Dauphine \\ Paris, France \\ Duane Truex \\ Computer Information Systems \\ Georgia State University \\ Atlanta, GA U.S.A.
}

\section{ABSTRACT}

This paper draws from 21 years of discourse to examine a narrative about IBM's transition to a service-oriented company. Covering three leadership eras during a period of sweeping change for IBM and the information technology industry, this discourse, found in the IBM Corporation's annual reports, in illustrates the emergence of policy, technology, and business models in one of the largest and most influential IT companies in the world. Our purpose in drawing from these texts is twofold: (1) to provide a more

Please use the following format when citing this chapter:

Carter, M., Takeda, H., and Truex, D., 2008, in IFIP International Federation for Information Processing, Volume 267, Information Technology in the Service Economy: Challenges and Possibilities for the $21^{\text {st }}$ Century, eds. Barrett, M., Davidson, E., Middleton, C., and DeGross, J. (Boston: Springer), pp. 367-370. 
thorough discussion of the notion of "emergence" in IT organizational settings, and (2) to introduce a fuller process model of how emergence is manifest in organizational discourse than is currently present.

In much of the information systems literature, the term emergence has been informally used in describing organizational contexts and the process of IS development (Markus and Robey 1988; Orlikowski 1996; Pfeffer and Leblebici, 1977). In three papers, Truex and his colleagues formally describe and situate a theory of emergence in the discourse on ISD methods (Truex and Baskerville 1998, Truex, Baskerville, and Klein 1999; Truex, Baskerville, and Travis 2000). They liken ISD to "emergent grammars" in a linguistic system. However, they stop short of developing a full epistemology of the notion and provide little more than analogical and descriptive examples grounded in linguist Paul Hopper's $(1987,1988)$ emergent grammar hypothesis. The incomplete development of the epistemology and an ontology of the emergence construct has proven problematic for scholars attempting to apply emergence theory in practice (Bello et al. 2002). While researchers or practitioners might find the idea of emergent organizations inviting, without descriptive and explanatory models, the concept is difficult to use in the practice or study of information systems. Accordingly, this paper seeks to contribute to the development of a theory of emergence.

We draw from the organizational communication and organizational discourse literature. In a subset of this community, scholars have advanced theories on the nature of organization as a discursive construction. For them, discourse is the very foundation on which "organization" is built (Fairhurst and Putnam 2004; Heracleous 2006; Heracleous and Barrett 2001; Taylor and Robichaud 2004; Taylor and Van Every 2000). Using this meta-theoretical framework, we explore how emergence arises through an examination of IBM's annual reports and industry-level discourses, which were, in turn, influenced in part by the IBM declarations and subsequent behavioral changes.

We introduce a new process model of organizational emergence by extending and addressing shortcomings in a set of current perspectives in the literature. The tripartite domain model identifies three domains - context, task, and negotiation-at-hand - as integral components of any concrete occurrence of discourse. To test its efficacy, we apply the tripartite domain model post hoc to a longitudinal set of IBM Corporation data. The tripartite domain model provides a lens to examine the servitization of IBM and, in the process, illustrates the emergent discourse on the notion of "service" and on the evolution of the meaning of "customer" in the IBM dataset.

\section{References}

Bello, M., Sorrentino, M., and Virili, F. 2002. "Web Services and Emergent Organizations: Opportunities and Challenges for IS Development," in Information Systems and the Future of the Digital Economy: $10^{\text {th }}$ European Conference on Information Systems, S. Wrycza (ed.), Gdansk, Poland, June 6-8.

Fairhurst, G. T., and Putnam, L. 2004. "Organizations as Discursive Constructions," Communication Theory (14), pp. 5-26.

Heracleous, L. 2006. Discourse, Interpretation, Organization, Cambridge, UK: Cambridge University Press. 
Heracleous, L., and Barrett, M. 2001. "Organizational Change as Discourse: Communicative Actions and Deep Structures in the Context of Information Technology Implementation," Academy of Management Journal (44), pp. 755-778.

Hopper, P. 1987. “Emergent Grammar,” Berkeley Linguistics Society (13), pp. 139-157.

Hopper, P. 1988. "Emergent Grammar and the a priori Grammar Postulate," in Linguistics in Context: Connecting Observation and Understanding, Vol. XXIX, D. Tannen (ed.), Norwood, NJ: Ablex Publishing, pp. 117-134.

Markus, M. L., and Robey, D. 1988. "Information Technology and Organizational Change: Causal Structure in Theory and Research," Management Science (34), pp. 583-598.

Orlikowski, W. J. 1996. "Improvising Organizational Transformation Over Time: A Situated Change Perspective," Information Systems Research (7), pp. 63-92.

Pfeffer, J., and Leblebici, H. 1977. "Information Technology and Organizational Structure," The Pacific Sociological Review (20), pp. 241-261.

Taylor, J. R., and Robichaud, D. 2004. "Finding the Organization in the Communication: Discourse as Action and Sensemaking," Organization, (11), pp. 395-413.

Taylor, J. R., and Van Every, E. J. 2000. The Emergent Organization: Communication as Its Site and Surface, Mahwah, NJ: Lawrence Erlbaum Associates.

Truex, D. P., and Baskerville, R. 1998. "Deep Structure or Emergence Theory: Contrasting Theoretical Foundations for Information Systems Development," Information Systems Journal (8), pp. 99-118.

Truex, D. P., Baskerville, R., and Klein, H. 1999. "Growing Systems in Emergent Organizations," Communications of the ACM (42), pp. 117-123.

Truex, D. P., Baskerville, R., and Travis, J. 2000. “Amethodical Systems Development: The Deferred Meaning of Systems Development Methods," Accounting Management and Information Technologies (10), pp. 53-79.

\section{About the Authors}

Michelle Carter is pursuing her Ph.D at Clemson University. She has Master' degrees in Computer Science (Anglia Polytechnic University, UK) and Management Information Systems (Georgia State University). Her research interests, informed by a decade in IS development, include managing project risk through requirements validation, how organizations emerge in ISrelated communicative actions, and technology adoption in developing economies. Her research has appeared in the proceedings of the SAIS, AMCIS, IFIP OASIS, and IFIP WG.8.2. Michelle can be reached at mscarte@clemson.edu.

Hirotoshi Takeda is a Graduate Advancement Program Fellow and Ph.D. student in Computer Information Systems at Georgia State University and the University of Paris Dauphine. He has degrees in electrical engineering and computer science from the University of California, Irvine, a Master's of Electrical Engineering from Georgia Institute of Technology, and an MBA from Southern Methodist University. His research interests include discourse analysis, mobile computing, bibliometrics and knowledge management. His research has appeared in the proceedings of the SAIS, UKAIS, ISECON, IFIP WG 8.2, ICIS SIG-ED, and SIG MIS. Hirotoshi can be reached at htakeda@cis.gsu.edu.

Duane Truex, an associate professor in the Department of Computer Information Systems and the Institute for International Business at Georgia State University, is interested in the social impacts of IS on social organizations and how emergent properties of organizations may be reflected in emergent ISD. Duane is active in the IFIP WG 8.2 and 8.6 communities, is an associate editor of Information Systems Journal, has edited for Database for Advances in Information Systems, and serves on several other journal editorial boards. His work has appeared 
in the Communications of the ACM, Accounting Management and Information Technologies, Communications of the AIS, DataBase, European Journal of Information Systems (EJIS), Information Systems Journal, Journal of the AIS, Journal of Arts Management and Law, IEEE Transactions on Engineering Management, Scandinavian Journal of Information Systems, Le Journal Systè mes d'Information et Management, and more than 60 IFIP transactions and edited books and conference proceedings. Duane can be reached at dtruex@gsu.edu. 